\title{
BUITENGEWONE BESTUURSVERGADERING,
}

GeHouden NA AFLoop der ALgFMeEne vergadering, 26 Februari 1881.

Tegenwoordig de heeren: van Rappard, Kniphorst, Robidé ven der Aa, Lammers van Toorenburg, Quarles van Ufford, van der Gon Netscher, Juynboll, Meinsma , Niemann en Wijnmalen.

De Voorzitter, de heer van Rappard, heet het nieuwbenoemd Bestuurslid, Prof. G. K. Niemann, welkom, terwijl hij hem bij vernieuwing de zorg voor de belangen van het Institurt aanbeveelt.

Ter voldoening aan het voorschrift, vervat in art. 9 van het Reglement, worden vervolgens bij acclamatie, zonder hoofdelijke stemming, tot Voorzitter, Ondervoorzitter en Penningmeester herbenoemd de heeren van Rappard, van Goltstein en Kniphorst.

Terwijl aan den heer van Goltstein van zijne herbenoeming tot Ondervoorzitter zal worden kennis gegeven, verklaren de heeren van Rappard en Kniphorst, onder dankbetuiging voor het in hen gesteld vertrouwen, bereid te zijn hunne functiën te blijven vervullen.

Daar de heer Wijnmalen als lid van het Bestuur is afgetreden en derhalve ook zijn ontslag heeft aangevraagd als Secretaris, geeft de Voorzitter in overweging ditmaal weder gebruik te maken van de aan het Bestuur verleende bevoegdheid om een Secretaris, buiten het Bestuur, uit de gewone leden te benoemen. Dienovereenkomstig wordt besloten, waarop, zonder hoofdelijke stemming bij acclamatie, de heer Wijnmalen tot Secretaris wordt benoemd.

Dankbaar voor de hem toegedachte onderscheiding, verklaart de heer Wijnmalen zich bereid opnieuw het Secretariaat te aanvaarden, onder uitdrukkelijke voorwaarde echter dat 
het Bestuur hem de noodige hulp verstrekke bij de vervulling zijner omvangrijke dubbele taak.

Overeenkomstig het voorstel des Voorzitters wordt de Secretaris uitgenoodigd in de eerstvolgende Bestuursvergadering zoodanige voorstellen te doen als welke zijns inziens noodig zijn ter vervulling van de door hem gestelde voorwaarde.

Niets meer hierna aan de orde zijnde, wordt de Vergadering door den Voorzitter gesloten. 